\title{
Corporate Social Responsibility (CSR) Practices and Stakeholders Expectations: The Nigerian Perspectives
}

\author{
Fadun, Solomon Olajide (Corresponding author) \\ Glasgow School of Business and Society, Glasgow Caledonian University, Glasgow, UK \\ E-mail: sofadun@yahoo.co.uk
}

Received: February 10, 2014 Accepted: March 6, 2014 Published: March 11, 2014

doi:10.5296/rbm.v1i2.5500 URL: http://dx.doi.org/10.5296/rbm.v1i2.5500

\begin{abstract}
Using Carroll's (1991) Corporate Social Responsibility (CSR) model, the study examines business CSR practices and stakeholders' expectations in Nigeria. Carroll's (1991) CSR model states that four kinds of social responsibilities constitute total CSR: economic, legal, ethical, and philanthropic. Both primary (survey) and secondary (the literature) data are used for the study. There are several stakeholders in business; but, for the purpose of the study employees, customers, shareholders, and local communities are identified as the main stakeholders in the context of the business environment in Nigeria. 240 questionnaires are administered to participants, selected through purposive sampling technique, in the six geopolitical zones of Nigeria. One hundred and fifty eight (158) questionnaires, representing $66 \%$ response rate, were duly completed and retuned for the study. The findings indicate that CSR is concerned with treating stakeholders ethically; and business should protect wide range of stakeholders' interest. We found that the four dimensions of CSR (economic, legal, ethical and philanthropic) are not ascribed equal importance in Nigeria. Nigeria's Stakeholders place more emphasis on economic, legal and ethical responsibilities than on philanthropic components. Understanding and effective management of stakeholders' as well as their expectations can enhance corporate image and competitive advantage. The implication for practice is that business needs to identify relevant stakeholders and integrate primary stakeholders' interests into organisational strategic planning. It shows that identification of stakeholders' groups is beneficial to business managers and decision-makers.
\end{abstract}

Keywords: corporate social responsibility, stakeholders expectations, stakeholder theory, stakeholder management, Nigeria 


\section{Introduction}

The concept of corporate social responsibility (CSR) focuses on ethical and moral issue which impact corporate decision making and behaviour. CSR is a concept that emphasises responsive and extended social contribution of businesses to the society. Likewise, globalisation has reinforced the relevancy of CSR in business operations. This is because globalisation has introduced new challenges and opportunities emanating from increasing linkages between social, political, economical and environmental roles of businesses. Thus, businesses are confronted with new risks in the global dynamic environment. The implication is that businesses need to be profitable and respond positively to emerging societal expectations accordingly. The main purpose of CSR is to ensure that firms are accountable to stakeholders. Firms deal with a wide range of stakeholders, including: shareholders, customers, employees, trade unions and community (Carroll, 1991; Hillenbrand \& Money, 2007; Carroll \& Shabana, 2010; Kemper et al., 2013). Since business have limited resources to devote to CSR activities; hence, firms need to identify, prioritise and incorporate stakeholders in decision-making. Naturally, business seeks to maximise its profits and is self-interested (Friedman, 1970; Bakan, 2004; Fisher \& Lovell, 2009; Hooker, 2011). However, a firm has social responsibilities, as its strategic decisions often affect wide range of stakeholders. CSR practices have become a component of business organisation that enhance competitive advantage and long-term sustainability (Porter \& Kramer, 2006; Halme \& Laurila, 2009; Brik et al., 2010; Carroll \& Shabana, 2010; Rodriguez-Melo \& Mansouri, 2011; Kemper et al., 2013; Monowar \& Humphrey, 2013). The study uses Carroll's (1991) CSR model as the main theoretical framework for examining firms CSR practices and stakeholders' expectations in Nigeria. Carroll's (1991) CSR model states that four kinds of social responsibilities constitute total CSR: economic, legal, ethical, and philanthropic (Carroll, 1979, 1991). Using Carroll's (1991) CSR model, the study examines business CSR practices and stakeholders' expectations in Nigeria. It considers business as an entity; explains the concept of CSR; explores stakeholder' theory; explains stakeholder's management; and outlines theoretical framework of the study.

\section{Aim, Objectives and Significance of Study}

The study examines stakeholders' expectations of firms CSR practices in Nigeria. The objectives of the study include, to:

a) explore the concept of CSR;

b) highlight components of CSR using Carroll model; and

c) identify stakeholders and stakeholders' expectations regarding CSR.

Business organisations have several stakeholders; however, for the purpose of the study we identified: employees, customers, shareholders, and local communities as the main stakeholders in the context of the business environment in Nigeria. Since social, cultural, and political histories and backgrounds differ from country to country; we envisaged that stakeholder' expectations of CSR activities would differ. The study is significant and contributes to knowledge as its findings would assist businesses in Nigeria to understand 
stakeholders' expectations and to improve CSR activities.

\section{Methodology}

Survey and quantitative research strategies are adopted for the study. The motivation for adopting survey for the study stems from its potential to provide a better statistical sample. Quantitative approach is well suited for the study as: it facilitates examination and explanation of relationship between variables; and, a conclusion can be drawn from the sample about the population to achieve the research objective. Two hundred and forty (240) structured questionnaires are administered to participants, selected through purposive sampling technique, in the six geopolitical zones of Nigeria. The questionnaire contained 22 questions, divided into four sections. A pilot survey was undertaken with 20 business managers and stakeholders, to ensure that the questionnaire is adequate and suitable for the study. The survey responses are processed and analysed with SPSS/PASW. There are several stakeholders in business; however, for the purpose of the study we identified: employees, customers, shareholders, and local communities as the main stakeholders in the context of the business environment in Nigeria.

\section{Theoretical and Conceptual Frameworks}

Most business decisions involve social and environmental issues. A major debate in business ethics centred on whether managers should be concern primarily on the interests of shareholders and whether they should consider or balance the interest of wide stakeholders (Campbell, 2007; Agle et al., 2008; Freeman, 2008). Managerial perspective is concerned mainly with protection of shareholders interest; but, the stakeholder perspective emphasises the need to consider wide range of stakeholders interest (Crane \& Matten, 2010; Carroll, \& Buchholtz, 2011). The contribution of CSR activities to business is doubtful; as classic economists and advocates of agency theory assert that organisational wealth and shareholder benefits maximisation should be the major concern of business (Friedman, 1962, 1970; Jansen, 2002). They argue that the concept of CSR could be contrary and detrimental to the main objective of business - to earn profits (Friedman, 1962, 1970). Conversely, other scholars argue that business have some obligations and responsibilities towards society; hence, they should do something for the benefit and welfare of the society (Margolis \& Walsh, 2003; Gifford \& Kestler, 2008). Using Carroll's (1991) CSR model, the study explores stakeholders' expectations of business CSR practice in Nigeria. The chapter reviews relevant literature regarding the study.

\subsection{Conceptual Framework}

\subsubsection{Business as an Entity}

Corporation is defined in terms of legal status and ownership of assets. The law sees corporations as artificial persons that exist independently of their shareholders; and has certain rights and responsibilities (Fisher \& Lovell, 2009; Crane \& Matten, 2010; Ghillyer, 2012). A corporation (firm) needs to act or perform responsibly for two main reasons: business related self-interests and moral reasons (Bakan, 2004; Fisher \& Lovell, 2009; Hooker, 2011). Managers have the responsibility to protect shareholders' investment. 


\section{MInstitute Macrothink $_{\text {Int }}$}

However, manager actions impact other interested parties (stakeholders), other than shareholders. Furthermore, some degree of responsibility is accredited to corporations because every organisation has a corporate internal decision-making structure to achieved predetermined goals (Friedman, 1970; Brews \& Purohit, 2007; Czinkota et al., 2011: Hill \& Jones, 2012); and all organisations manifest organisational structure which highlight beliefs and values as to what is generally regarded as right or wrong in the corporation (Kelly, 2009; Kefela, 2010; Schein, 2010).

\subsubsection{The Concept of CSR}

CSR is highly complex and contentious issue among academics and practitioners. There is lack of consensus regarding definition and contents of CSR practices (Dahlsrud, 2008; Dobers, 2009; Carroll \& Shabana, 2010; Taneja et al., 2011). The concept and terminology of CSR also varies as some firms refer to it as: corporate social performance, corporate social responsiveness, corporate citizenship, ethical business practices, stakeholder management, and corporate sustainable business practices (Basu \& Palazzo, 2008; Carroll \& Shabana, 2010; Sharma \& Kiran, 2013). CSR advocates that businesses have responsibilities, which extend beyond making a profit, to society. Notwithstanding, a firm has social responsibilities, and is ethical responsible for its action because its strategic decisions often affect other stakeholders. For example, a firm decision to retrench employees affects not only the firm's workforce but also affect other stakeholders, include: local communities; government; general public; and customers. Hence, Bernstein (2000) argues that business should be responsible to stakeholders even if it requires firms to sacrifice some profits. Firms should deal with these conflicting interests and claims in an ethical manner by formulating stakeholders' friendly policies. This is consistent with the assertion of Carroll and Buchholz (2011) that CSR includes economic, legal, ethical, and philanthropic expectations placed on businesses by the society. CSR is a commitment to improve community well-being through discretionary business practices and contributions of corporate resources (Kotler \& Lee, 2005). Zadek (2000) argues that firms engage CSR strategies to: protect/defend their reputations; justify benefits over costs; integrate stakeholders into their strategies; and understand, innovate and manage risk. There are several benefits firms derived for engaging in CSR activities. Kurucz et al. (2008) categorise benefits firms derive from engaging in CSR activities into four: cost and risk reduction; gaining competitive advantage; developing reputation and legitimacy; and seeking win-win outcomes through synergistic value creation. CSR, therefore, promotes healthy relationship between business and the larger society, by redefining the role and obligations of private business within that society (Keinert, 2008).

\subsubsection{Stakeholder Theory}

Stakeholder theory emphasises that beyond shareholders there are several agents that are interested in firms' actions and decisions. The theory highlights the need for managers to be accountable to stakeholders. Stakeholders are individuals or groups which were either harmed by or benefits from the corporation; or whose rights have been violated or have to be respected by the corporation (Freeman, 1984; Jensen, 2001; Hosmer, 2011; Trevino \& Nelson, 2011). Firms have several stakeholders which compete for organisational resources; hence, 
the need for firms to identify strategies for managing stakeholders (Bryson, 2005; Reynolds et al., 2006; Michelon et al., 2013). The type of stakeholders proactively engaged and resources control strategy adopted impact firms corporate strategy (Kolk \& Pinkse, 2007; Carroll \& Shabana, 2010). From a business-driven viewpoint, stakeholder theory interest covers three premises: that organisations have stakeholders which impact their activities; these interactions impact on specific stakeholders and the organisation; and perceptions of major stakeholders impact the viability of organisational strategic options (Simmons, 2004; Branco \& Rodrigues, 2007; Hillenbrand \& Money, 2007). Firms, therefore, need to adopt suitable approaches to deal with primary stakeholders accordingly (Jawahar \& McLaughlin, 2001; Carroll \& Buchholtz, 2011). Firms are unlikely to fulfil responsibilities (economic and non-economic) of some primary stakeholders; hence, the need for stakeholders management.

\subsubsection{Stakeholders' Management}

The obligation to serve all stakeholders' interests is often referred to as stakeholder management (Post et al., 2002; Bowie, 2004; Boatright, 2006). Since corporations deal with several stakeholder over time and simultaneously; it is unlikely that organisations would fulfil all their responsibilities towards each primary stakeholders or groups (Freeman, 1984; Jawahar and McLaughlin, 2001; Wicks et al., 2010). Hence, firms' should identify strategies for managing stakeholders as there are several stakeholders competing for organisational resources (Reynolds et al., 2006; Branco \& Rodrigues, 2007). Furthermore, the type of stakeholders engage, and resources control strategy adopted impact organisation's corporate strategy (Kolk \& Pinkse, 2007). Stakeholder management facilitates consideration of individuals or groups within and outside the firm when allocating organisational resources. Stakeholder management promotes effective allocation of resources among stakeholders to achieve a 'win-win' outcome.

\subsection{Theoretical Framework}

CSR benefits both the society and business for improved performance and social reputation (Matten \& Moon, 2008, Monowar \& Humphrey, 2013). Carroll's (1991) CSR model is used as the main theoretical framework for examining CSR practices of Nigeria's business environment. The model is adopted because it is comprehensive and highlights important issues of the CSR debate. The model focuses on main areas of CSR and their relative importance. Although the classification of CSR activities is still contentious, Carroll's (1991) pyramid of CSR (Fig. 1) is considered the most acceptable model (Geva, 2008; Carroll \& Shabana, 2010; Taneja et al., 2011; Carroll \& Buchholtz, 2011). Carroll (1991) defines CSR as encompassing "economic, legal, ethical and discretionary expectations that society has placed on organisations". Carroll's model of CSR states that four kinds of social responsibilities constitute total CSR: economic, legal, ethical, and philanthropic (Carroll, 1979, 1991). 


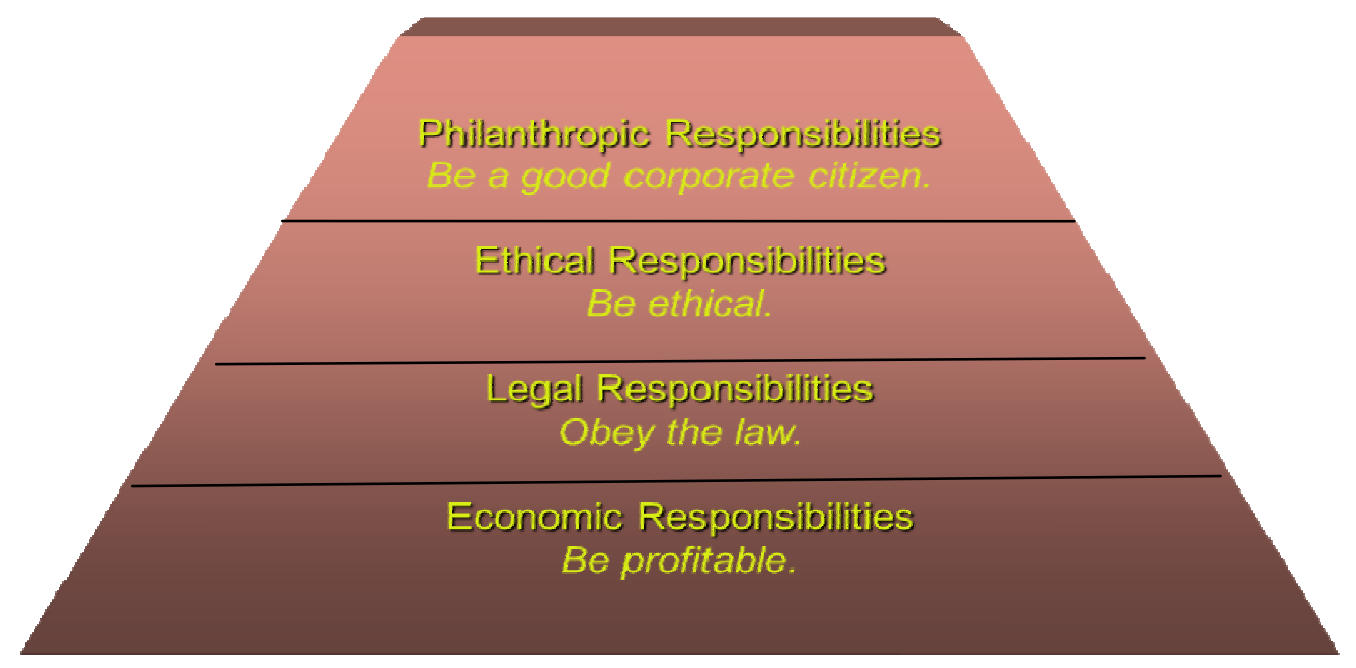

Figure 1. Carroll's Pyramid of CSR

\subsubsection{Economic Responsibilities}

Firms are economic entities established to provide goods and services to society. Profit motive (profit maximisation) is the primary incentive for entrepreneurship. Managers, as agents of the company owners, are oblige to maximise shareholders wealth. Carroll's economic component emphasises the need for a business organisation to: perform in a manner consistent with maximising earnings per share; be committed to being profitable as possible; maintain a strong competitive position; maintain a high level of operating efficiency; and that a successful firm be defined as one that is consistently profitable (Carroll, 1991:40). However, Barnett (2007) argues that excessive financial performance is not in the interest of stakeholders.

\subsubsection{Legal Responsibilities}

Whilst a business organisation is permitted to operate according to profit motive (economic responsibility); firms are expected to comply with laws and regulations (legal responsibility). Legal responsibilities embody basic notions of fair operations as promulgated by federal, state and local governments. Carroll's legal component stresses the need for a firm to: perform in a manner consistent with expectations of government and law; be a law-abiding corporate citizen; provide goods and services that meet minimal legal requirements; and that a successful firm be defined as one that fulfils its legal obligations (Carroll, 1991:40). Moreover, some scholars argue that regulation is necessary for the fulfilment of CSR (Phillips et al., 2003; De Schutter, 2008).

\subsubsection{Ethical Responsibilities}

Whilst economic and legal responsibilities incorporate ethical rules about fairness and justice; ethical responsibilities encompass activities and practices that are acceptable or unacceptable by the society, though not codified into law. Ethical responsibilities refer to strategic managers' values about right and wrong business behaviour or conduct. Ethics or values are 
dynamic and precede the establishment of law. In essence, ethics are the driving force behind the creation of laws or regulations. Moreover, ethical responsibilities embrace society emerging values and norms which a business are expected to meet. Sometimes, such values and norms may require a higher standard of performance than that required by law. Carroll's ethical component advocates the need for a firm to: perform in a manner consistent with societal expectations and ethical norms; recognise and respect new or evolving ethical/moral norms adopted by society; and prevent ethical norms from being compromised in order to achieve corporate goals (Carroll, 1991:41).

\subsubsection{Philanthropic Responsibilities}

Philanthropy entails corporate actions, towards promoting human welfare or goodwill, in response to society's expectations that businesses should be good corporate citizens. Philanthropic responsibilities are voluntarily assumed by business; such as public relations, good citizenship, and contribution to education or community. The main difference between philanthropic and ethical responsibilities is that ethical components are expected in an ethical or moral sense, but philanthropic components are not. Philanthropy is voluntary or discretionary on the part of a business. Carroll's philanthropic component emphasises the need for a firm to: perform in a manner consistent with philanthropic and charitable expectations of society, and voluntarily assist projects that enhance a community's quality of life (Carroll 1991:41). In response to social and stakeholder concern, many firms in Nigeria are adopting policies directed at the ethical responsibilities of business.

\section{Hypothesis Formulation}

Different countries (including Nigeria) have different social, cultural, and political histories and backgrounds (Halme \& Laurila, 2009; Hiseh, 2009; Bagire et al., 2011; Adeyanju, 2012); hence, we expect that perceptions and expectations of stakeholders regarding CSR activities would differ (Wong et al., 2010; Adeyanju, 2012). Likewise, stakeholders' expectations and interests vary with organisational contexts (Kolk, 2008; Ramachandran, 2011). We presumed that firms in Nigeria are trying to implement some CSR activities to enhance their corporate images. Hence, we formulate a research hypothesis as follows:

Ho: In Nigeria, stakeholders' do not ascribe equal importance to the four dimensions of CSR activities.

Hi: In Nigeria, stakeholders' ascribed equal importance to the four dimensions of CSR activities.

\section{Data Analysis and Discussions}

\subsection{Survey Response and Response Rate}

One hundred and fifty eight (158) of the 240 administered questionnaires, representing $66 \%$ response rate, were duly completed and retuned for the study. The achievement of $66 \%$ response rate was greatly influenced by pre-survey contacts with participants, and subsequent reminders via emails, telephone calls and messages. The result reveals that 148 of the respondents representing $94 \%$ have heard about CSR. This suggests that majority of the 


\section{Al Macrothink}

respondents are aware about CSR; consequently, we envisaged objective and reliable results/findings. Furthermore, 94\% CSR awareness of the respondents' affirms the suitability of purposive sampling technique adopted for the study.

\subsection{Stakeholders'Perception of CSR (Questions 2 - 5)}

Respondents are required to indicate their level of agreement with statements on stakeholders' perception of CSR. The results are presented in Table 1. The analysis of responses revealed that: firms should treat stakeholders in a manner ethically acceptable in a civilised society; business should protect wide range of stakeholders' interest; business should protect wide range of stakeholders' interest; and business commitment to CSR is not a waste of organisational time and resources (Table 1).

Table 1: Stakeholders perception of CSR $(n=158)$

\begin{tabular}{|c|c|c|c|c|c|c|}
\hline Question & Response & 1 & 2 & 3 & 4 & 5 \\
\hline \multirow[t]{2}{*}{2} & $\begin{array}{l}\text { CSR is concerned with treating } \\
\text { stakeholders ethically or in a socially } \\
\text { responsible manner }\end{array}$ & 0 & 0 & 5 & 106 & 47 \\
\hline & & $0 \%$ & $0 \%$ & $3 \%$ & $67 \%$ & $30 \%$ \\
\hline \multirow[t]{2}{*}{3} & $\begin{array}{l}\text { Business should be concerned mainly } \\
\text { with the protection of shareholders } \\
\text { interest }\end{array}$ & 88 & 34 & 0 & 15 & 21 \\
\hline & & $56 \%$ & $22 \%$ & $0 \%$ & $9 \%$ & $13 \%$ \\
\hline \multirow[t]{2}{*}{4} & $\begin{array}{l}\text { Business should be concerned with } \\
\text { protection of wide range of stakeholders } \\
\text { interest }\end{array}$ & 9 & 9 & 0 & 38 & 102 \\
\hline & & $6 \%$ & $6 \%$ & $0 \%$ & $24 \%$ & $64 \%$ \\
\hline \multirow[t]{2}{*}{5} & $\begin{array}{l}\text { Business commitment to CSR is waste } \\
\text { of organisational time and resources }\end{array}$ & 46 & 106 & 6 & 0 & 0 \\
\hline & & $29 \%$ & $67 \%$ & $4 \%$ & $0 \%$ & $0 \%$ \\
\hline
\end{tabular}

NB: Strongly agree (5), Agree (4), Neither agree nor disagree (3), Disagree (2), and Strongly disagree (1).

\subsection{Section C: Importance Ascribed to CSR Practice (questions 6 - 10)}

Respondents are required to rate statements about CSR in business according to their importance. The results are presented in Table 2. The results indicated that: stakeholders' concern is perceived to be highly important, as a business need to develop appropriate strategies for managing stakeholders (Branco \& Rodrigues, 2007; Wicks et al., 2010); profitability of a business is highly important to stakeholders in Nigeria, as profitability enhances its operations and other auxiliary activities (Fontaine et al., 2006; Elkin, 2007; 


\section{Ml Macrothink}

Yilmaz and Gunel, 2008); stakeholders' in Nigeria expect businesses to be responsible corporate citizen, as businesses are expected to comply with laws (Schwartz \& Carroll, 2008; Steurer, 2010); stakeholders in Nigeria perceived philanthropic concern in business less important; and stakeholders in Nigeria considered ethical responsibility to be relevant in business, as power and influence of business in society is becoming greater than ever (Keith, 2010; Bernard et al., 2012).

Table 2. Importance Ascribed to CSR Practice by Stakeholders $(n=158)$

\begin{tabular}{|l|l|c|c|c|c|c|}
\hline Question & Response & 1 & 2 & 3 & 4 & 5 \\
\hline 6 & $\begin{array}{l}\text { How important is the stakeholders' } \\
\text { concerns in business? }\end{array}$ & 0 & 0 & 24 & 134 \\
\hline & \multicolumn{1}{|l}{$\begin{array}{l}\text { How important is profit concerns in } \\
\text { business? }\end{array}$} & 0 & 0 & 0 & 25 & 133 \\
\hline 7 & $\begin{array}{l}\text { How important is legal responsibility } \\
\text { concerns in business? }\end{array}$ & 9 & 6 & 0 & 20 & 123 \\
\hline 8 & $\begin{array}{l}\text { How important are voluntary actions } \\
\text { (philanthropic) concerns for the society } \\
\text { in business? }\end{array}$ & 96 & 16 & 6 & 34 & 6 \\
\hline 9 & $\begin{array}{l}\text { How important to integrate ethical } \\
\text { (obligation to do the right or fair things) } \\
\text { concerns in business? }\end{array}$ & 16 & 12 & 0 & 95 & 35 \\
\hline 10 & \begin{tabular}{l}
10 \\
\hline
\end{tabular} & $8 \%$ & $0 \%$ & $60 \%$ & $22 \%$ \\
\hline
\end{tabular}

NB: Very important (5), Important (4), Not sure (3), Less important (2), and Not important (1).

\subsection{CSR and Stakeholders Expectations (Questions 11 - 22)}

Respondents are required to indicate their level of agreement with statements about CSR and stakeholders' expectations in business. Based on Carroll's (1991) CSR pyramid; the section is divided into four parts/responsibilities - economic, legal, ethical, and philanthropic. The results are presented in Table 3. 
Table 3: CSR and Stakeholders Expectations $(n=158)$

\begin{tabular}{|c|c|c|c|c|c|c|}
\hline Question & Responsibility and Response & 1 & 2 & 3 & 4 & 5 \\
\hline & ECONOMIC RESPONSIBILITY & & & & & \\
\hline \multirow[t]{2}{*}{11} & $\begin{array}{l}\text { Business should be committed to being } \\
\text { profitable as possible }\end{array}$ & 4 & 6 & 0 & 26 & 122 \\
\hline & & $2 \%$ & $4 \%$ & $0 \%$ & $17 \%$ & $77 \%$ \\
\hline \multirow[t]{2}{*}{12} & $\begin{array}{l}\text { Business should maintain a strong competitive } \\
\text { position }\end{array}$ & 4 & 0 & 0 & 33 & 121 \\
\hline & & $3 \%$ & $0 \%$ & $0 \%$ & $21 \%$ & $76 \%$ \\
\hline \multirow[t]{3}{*}{13} & $\begin{array}{l}\text { Business should maintain a high level of } \\
\text { operating efficiency }\end{array}$ & 0 & 6 & 0 & 40 & 112 \\
\hline & & $0 \%$ & $4 \%$ & $0 \%$ & $25 \%$ & $71 \%$ \\
\hline & LEGAL RESPONSIBILITY & & & & & \\
\hline \multirow[t]{2}{*}{14} & $\begin{array}{l}\text { Business should perform in a manner consistent } \\
\text { with expectations of government and law }\end{array}$ & 0 & 4 & 0 & 23 & 131 \\
\hline & & $0 \%$ & $3 \%$ & $0 \%$ & $14 \%$ & $83 \%$ \\
\hline \multirow[t]{2}{*}{15} & $\begin{array}{l}\text { Business should be a law-abiding corporate } \\
\text { citizen }\end{array}$ & 2 & 2 & 0 & 33 & 121 \\
\hline & & $1 \%$ & $1 \%$ & $0 \%$ & $21 \%$ & $77 \%$ \\
\hline \multirow[t]{3}{*}{16} & $\begin{array}{l}\text { Business should provide goods and services that } \\
\text { meet minimal legal requirements }\end{array}$ & 2 & 4 & 0 & 37 & 115 \\
\hline & & $1 \%$ & $3 \%$ & $0 \%$ & $23 \%$ & $73 \%$ \\
\hline & ETHICAL RESPONSIBILITY & & & & & \\
\hline \multirow[t]{2}{*}{17} & $\begin{array}{l}\text { Business should perform in a manner consistent } \\
\text { with societal expectations and ethical norms }\end{array}$ & 6 & 16 & 0 & 120 & 16 \\
\hline & & $4 \%$ & $10 \%$ & $0 \%$ & $76 \%$ & $10 \%$ \\
\hline \multirow[t]{2}{*}{18} & $\begin{array}{l}\text { Business should recognise and respect new or } \\
\text { evolving ethical/moral norms adopted by society }\end{array}$ & 6 & 6 & 0 & 130 & 16 \\
\hline & & $4 \%$ & $4 \%$ & $0 \%$ & $82 \%$ & $10 \%$ \\
\hline \multirow[t]{3}{*}{19} & $\begin{array}{l}\text { Business should prevent ethical norms from } \\
\text { being compromised in order to achieve corporate } \\
\text { goals }\end{array}$ & 0 & 9 & 0 & 125 & 24 \\
\hline & & $0 \%$ & $6 \%$ & $0 \%$ & $79 \%$ & $15 \%$ \\
\hline & PHILANTHROPIC RESPONSIBILITY & & & & & \\
\hline \multirow[t]{2}{*}{20} & $\begin{array}{l}\text { Business should contribute resources to the } \\
\text { community }\end{array}$ & 87 & 40 & 0 & 13 & 18 \\
\hline & & $55 \%$ & $25 \%$ & $0 \%$ & $8 \%$ & $12 \%$ \\
\hline \multirow[t]{2}{*}{21} & $\begin{array}{l}\text { Business should perform in a manner consistent } \\
\text { with the philanthropic and charitable } \\
\text { expectations of society }\end{array}$ & 96 & 19 & 0 & 27 & 16 \\
\hline & & $61 \%$ & $12 \%$ & 0 & $17 \%$ & $10 \%$ \\
\hline \multirow[t]{2}{*}{22} & $\begin{array}{l}\text { Business should voluntarily support projects that } \\
\text { enhance the community's quality of life }\end{array}$ & 88 & 27 & 0 & 27 & 16 \\
\hline & & $56 \%$ & $17 \%$ & $0 \%$ & $17 \%$ & $10 \%$ \\
\hline
\end{tabular}

NB: Strongly agree (5), Agree (4), Neither agree nor disagree (3), Disagree (2), and Strongly disagree (1). 
6.4 CSR and Stakeholders Expectation - Economic Responsibility (Questions 11 - 13)

The findings (Table 3) on business economic responsibility suggest that Nigeria stakeholders' expect: business to be profitable, as profit motive is the primary incentive for entrepreneurship (Elkin, 2007; Yilmaz \& Gunel, 2008); business should maintain strong competitive position; and business should maintain a high level of operating efficiency, as there is positive link between strategic CSR and firm operating efficiency (Kemper et al., 2013; Michelon et al., 2013).

\subsection{CSR and Stakeholders Expectation - Legal Responsibility (Questions 14 - 16)}

The results (Table 3) on legal responsibility suggest that Nigeria stakeholders' expect: business to perform in a manner consistent with expectations of government and law; business to be a law-abiding corporate citizen, as business is expected to comply with legal requirements to satisfy the needs of various stakeholders (Fombrun et al., 2010; Mallin \& Michelon, 2011; Michelon et al., 2013); and business to offer goods and services which meet minimal legal requirements, in compliance with the law (Grossman, 2005; Falck \& Heblich, 2007; Dobers \& Springett, 2010).

\subsection{CSR and Stakeholders Expectation - Ethical Responsibility (Questions 17 - 19)}

The results (Table 3) on ethical responsibility suggest that Nigeria stakeholders' expect: business to perform in a manner consistent with societal expectations and ethical norms, as business has certain rights and responsibilities (Crane \& Matten, 2010; Ghillyer, 2012); business to recognise and respect new or evolving ethical/moral norms, so as to ensure that business proactively respond to relevant stakeholders (Neville and Menguc, 2006; Carroll \& Shabana, 2010); and business should not compromise ethical norms while pursuing organisational goals.

\subsection{CSR and Stakeholders Expectation - Philanthropic responsibility (Questions 20 - 22)}

The results (Table 3) on philanthropic responsibility indicate that Nigeria's stakeholders: pay less attention to contribution of business resources to the community; business philanthropic activities by way of supporting projects that enhance the community's quality of life should be voluntarily.

\section{Hypothesis Testing}

Ho: In Nigeria, stakeholders' do not ascribe equal importance to the four dimensions of CSR activities.

The research hypothesis is validated with questions $7-10$ responses which focus on importance ascribed to CSR activities by stakeholders in Nigeria. Summary of results are presented in Table 4 and Fig. 1. The result shows that equal importance is not ascribed to the four dimensions of CSR activities in Nigeria. From Nigeria's stakeholders' perspectives; stakeholders' concern is perceived to be highly important in business. Stakeholders place more emphasis on economic, legal and ethical responsibilities than on philanthropic responsibility. This may be due to the on-going economic restructuring, legal framework 


\section{Macrothink Institute ${ }^{\mathrm{TM}}$}

enhancement and financial sector consolidation in Nigeria. However, the findings reveal that economic responsibility is adjudged most importance by stakeholders in Nigeria; followed by legal and ethical responsibilities. This is consistent with Carroll's (1991) CSR model. To develop positive corporate image, firms need to consider stakeholders expectation before formulating CSR policies (Dober \& Halme, 2009; Eweje \& Palakshappa, 2009; Veleva, 2010; Bagire et al., 2011; Epstein \& Widner, 2011). Business is also expected to be responsible corporate citizen by complying with laws and regulations (Schwartz \& Carroll, 2008; Steurer, 2010). Similarly, ethical responsibility is relevance in business, as power and influence of business in society is becoming greater than ever (Keith, 2010; Bernard et al., 2012).

Table 6. Dimension of CSR activities in Nigeria according to level of importance

\begin{tabular}{|l|c|}
\hline Dimension of CSR Activities & $\begin{array}{l}\text { Importance ascribed to CSR } \\
\text { activities (\%) }\end{array}$ \\
\hline Profit Concerns - Economic Responsibility & 100 \\
\hline Legal Concerns - Legal Responsibility & 90 \\
\hline Ethical Concerns - Ethical Responsibility & 82 \\
\hline Voluntary action Concerns - Philanthropic Responsibility & 25 \\
\hline
\end{tabular}

NB: The figure consist of both important and very important (i.e. important + very important).

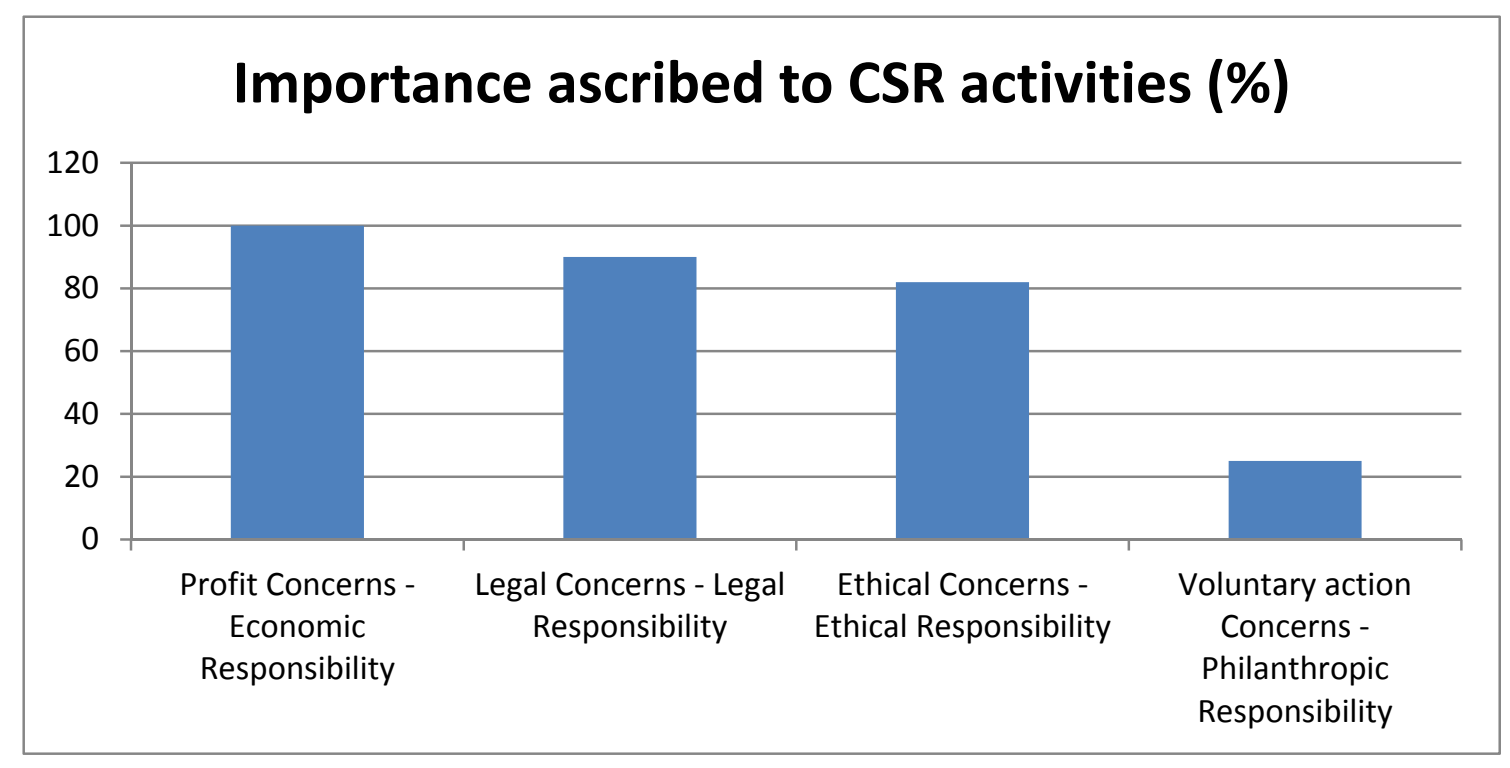

Figure 1: Dimension of CSR activities in Nigeria according to level of importance

NB: The figure consists of both important and very important (i.e. important + very important).

\section{Conclusion}




\section{Macrothink}

Research in Business and Management ISSN 2330-8362 2014, Vol. 1, No. 2

Using Carroll's (1991) CSR model, the study examines business CSR and stakeholders' expectations in Nigeria. Carroll's (1991) CSR model states that four kinds of social responsibilities constitute total CSR: economic, legal, ethical, and philanthropic. It considers business as an entity; explains the concept of CSR; explores stakeholder' theory; explains stakeholder's management; and outlines theoretical framework of the study. The study findings indicate that CSR is concerned with treating stakeholders ethically; and business should protect wide range of stakeholders' interest. We found that the four dimensions of CSR (economic, legal, ethical and philanthropic) are not ascribed equal importance in Nigeria. Stakeholders place more emphasis on economic, legal and ethical responsibilities than on philanthropic components. Understanding and effective management of stakeholders' as well as their expectations can enhance corporate image and competitive advantage. The implication for practice is that business needs to identify relevant stakeholders and integrate primary stakeholders' interests into organisational strategic planning. It shows that identification of stakeholders' groups is beneficial to business managers and decision-makers.

\section{References}

Adeyanju, O. D. (2012). An assessment of the impact of corporate social responsibility on Nigerian society: The examples of banking and communication industries. Universal Journal of Marketing and Business Research, 1(1), 17-43.

Agle, B. R., Donaldson, T., Freeman, R. E., Jensen, M. C., Mitchell, R. K., \& Wood, D. D. J. (2008). Dialogue: Toward superior stakeholder theory. Business Ethics Quarterly, 18(2), 153-190.

Bagire, V., Tusiime, I., Nalweyiso, G., \& Kokooza, J. (2011). Contextual environment and stakeholder perception of corporate social responsibility practice in Uganda. Corporate Social Responsibility and Environmental Management, 18(2), 102-109. http://dx.doi.org/10.1002/csr.252

Bakan, J. (2004). The corporation: The pathological pursuit of profit and power. New York: Free Press.

Barnett, M. L. (2007). Stakeholder influence capacity and the variability of financial returns to corporate social responsibility. Academy of Management Review, 32, 794-816. http://dx.doi.org/10.5465/AMR.2007.25275520

Basu, K., \& Palazzo, G. (2008). Corporate social responsibility: A process model of sense Making. The Academy of Management Review, 33(1), 122-136. http://dx.doi.org/10.5465/AMR.2008.27745504

Bernard, A. B., Jensen, J. B., Redding, S. J., \& Schott, P. K. (2012). The empirics of firm heterogeneity and international trade. Annual Review of Economics, 4, 283-313. http://dx.doi.org/10.2139/ssrn.2201804

Bernard, H. R. (2002). Research methods in anthropology: Qualitative and quantitative methods (3rd ed.). Walnut Creek, California: AltaMira. 


\section{Macrothink}

Bernstein, A. (2000). Too much corporate power. BusinessWeek, 11 September, 149.

Blomgren A. (2011). Does corporate social responsibility influence profit margin? A case study of executive perceptions. Corporate Social Responsibility and Environmental Management, 18, 263-274. http://dx.doi.org/10.1002/csr.246

Boatright, J. R. (2006). What's wrong and what's right with stakeholder management. Journal of Private Enterprise, 21(2), 106-131.

Bowie, N. E. (2004). Management ethics. Malden, MA: Blackwell.

Branco, M. C., \& Rodrigues, L. L. (2007). Positioning stakeholder theory within the debate on corporate social responsibility. EJBO Electronic Journal of Business Ethics and Organization Studies, 12(1), 5-15. Retrieved from http://urn.fi/URN:NBN:fi:jyu201010042899

Brews, P., \& Purohit, D. (2007). Strategic planning in unstable environments. Long Range Planning, 64-83.

Brik, A., Rettab, B., \& Mellahi, K. (2010). Market orientation, corporate social responsibility and business performance. Journal of Business Ethics, 99(3), 307-324. http://dx.doi.org/10.1108/17471111211247910

Bryson, J. (2005). What to do when stakeholders matter. Public Management Review, 6(1), 21-53.

Campbell, J. (2007). Why would corporations behave in socially responsible ways? An institutional theory of corporate social responsibility. Academy of Management Review, 32(3), 946-967. http://dx.doi.org/10.5465/AMR.2007.25275684

Carroll, A. B. (1979). A three dimensional conceptual model of corporate social performance. Academy of Management Review, 4, 497-505.

Carroll, A. B. (1991). The pyramid of corporate social responsibility: Toward the moral management of organisational stakeholders. Business Horizons, 39-48.

Carroll, A. B., \& Buchholtz, A. K. (2011). Business and society: Ethics and stakeholder management (8 ed.). Australia: Thomson South-Western.

Carroll, A., \& Shabana, K. (2010). The business case for corporate social responsibility: A review of concepts, research and practice. International Journal of Management Reviews, 12(1), 85-105. http://dx.doi.org/10.1111/j.1468-2370.2009.00275.x

Crane, A., \& Matten, D. (2010). Business ethics: Managing corporate citizenship and sustainability in the age of globalisation (3 ed.). New York: Oxford University.

Creswell, J. W. (2009). Research design: Qualitative, quantitative, and mixed methods approaches (3 ed.). London: Sage.

Czinkota, M. R., Ronkainen, I. A., \& Moffett, M. H. (2011). International business (8 ed.). Danvers, MA: John Wiley. 
Dahlsrud, A. (2008). How corporate social responsibility is defined: An analysis of 37 definitions. Corporate Social Responsibility and Environmental Management, 15, 1-13. http://dx.doi.org/10.1002/csr.132

De Schutter, O. (2008). Corporate social responsibility European style. European Law Journal, 14, 203-236. http://dx.doi.org/10.1111/j.1468-0386.2007.00411.x

Dobers, P. (2009). Corporate social responsibility: Management and methods. Corporate Social Responsibility and Environmental Management, 16(4), 185-191. http://dx.doi.org/10.1002/csr.201

Dobers, P., \& Halme, M. (2009). Corporate social responsibility and developing countries. Corporate Social Responsibility and Environmental Management, 16(5), 237-249.

Epstein, M., \& Widener, S. (2011). Facilitating sustainable development decisions: Measuring stakeholder reactions. Business Strategy and the Environment, 20(2), 107-123. http://dx.doi.org/10.1002/bse.680

Eweje, G., \& Palakshappa, N. (2009). Business partnerships with non-profits: Working to solve mutual problems in New Zealand. Corporate Social Responsibility and Environmental Management, 16(6), 337-351. http://dx.doi.org/10.1002/csr.192

Falck, O., \& Heblich, S. (2007). Corporate social responsibility: Doing well by doing good. Business Horizons, 50, 247-254. http://dx.doi.org/10.1016/j.bushor.2006.12.002

Fisher, C., \& Lovell, A. (2009). Business ethics and values. Harlow: FT Press.

Fombrun, C. J., Gardberg, N., \& Barnett, M. (2000). Opportunity platforms and safety nets: Corporate citizenship and reputational risk. Business and Society Review, 105, 85-106. http://dx.doi.org/10.1111/0045-3609.00066

Freeman, E. (2008). Ending the so-called Friedman-Freeman debate. Business Ethics Quarterly, 18(2), 162-165.

Freeman, R. E. (1984). Strategic management: A stakeholder approach. London: Pitman.

Friedman, M. (1962). Capitalism and freedom. Chicage: IL: Chicago University.

Friedman, M. (1970). The social responsibility of business is to increase its profits. New York Times Magazine, 32-33, 122, 126.

Geva, A. (2008). Three models of corporate social responsibility: Interrelationships between theory, research, and practice. Business and Society Review, 113(1), 1-41. http://dx.doi.org/10.1111/j.1467-8594.2008.00311.x

Ghillyer, A. (2012). Business Ethics Now (3 ed.). Boston, MA: McGraw-Hill.

Gifford, B., \& Kestler, A. (2008). Toward a theory of local legitimacy by MNCs in developing nations: Newmont mining and health sustainable development in Peru. Journal of International Management, 14, 340-352. http://dx.doi.org/10.1016/j.intman.2007.09.005 


\section{Macrothink Institute ${ }^{\text {TM }}$}

Grossman, H. A. (2005). Refining the role of the corporation: The impact of corporate social responsibility on shareholder primacy theory. Deakin Law Review, 10(2), 572-596.

Halme, M, \& Laurila, J. (2009). Philanthropy, integration, or innovation? Exploring the financial and social outcomes of different types of corporate responsibility. Journal of Business Ethics, 84, 325-339. http://dx.doi.org/10.1007/s10551-008-9712-5

Hill, C. W., \& Jones, G. R. (2012) Strategic management theory: An integrated approach (10 ed.). South-Western: Cengage Learning.

Hillenbrand, C., \& Money, K. (2007). Corporate responsibility and corporate reputation: Two separate concepts or two sides of the same coin? Corporate Reputation Review, 10(4), 261-277. http://dx.doi.org/10.1057/palgrave.crr.1550057

Hiseh, N. ( 2009). Corporate social responsibility and the priority of shareholders. Journal of Business Ethics, 88, 553-560. http://dx.doi.org/10.1007/s10551-009-0314-7

Hooker, J. (2011). Business ethics as rational choice. Harlow: Prentice Hall.

Hosmer, L. R. (2011). The Ethics of Management (7 ed.). Boston, MA: McGraw-Hill.

http://dx.doi.org/10.1016/j.jbusres.2013.02.018

Iamandi, I. E. (2007). Corporate social responsibility and social responsiveness in a global business environment: A comparative theoretical approach. Romanian Economic Journal, 10(23), 3-18.

Jansen, M. (2002). Value maximization, stakeholder theory and the corporate objective function. Business Ethics Quarterly, 12(2), 235-256.

Jawahar, I. M., \& McLaughlin, G. L. (2001). Toward a descriptive stakeholder theory: An organizational life cycle approach. The Academy of Management Review, 26(3), 397-414.

Jensen, M. C. (2001). Value maximisation, stakeholder theory and the corporate objective function. Journal of Applied Corporate Finance, 14(3), 8-21.

Johnson, B., \& Christensen, L. (2012). Educational research: Quantitative, qualitative, and mixed approaches (5 ed.). Thousand Oaks, CA: Sage.

Kefela, G. T. (2010). Understanding organisational culture and leadership: Enhance efficiency and productivity. PM World Today, 12(1), 1-13.

Keinert C. (2008). Corporate social responsibility as an international strategy. Heidelberg: Physica-Werlag A Springer Company.

Keith, N. (2010). Evolution of corporate accountability: From moral panic to corporate social responsibility. Business Law International, 11(3), 247-276.

Kelly, P. (2009). Conceptualising business risk culture: A study of risk thinking and practice in contemporary dynamic organisations. International Journal of Business Continuity and 
Risk Management, 1(1), 19-37. http://dx.doi.org/10.1504/IJBCRM.2009.028949

Kemper, J., Schilke, O., Reimann, M., Wang, X., \& Brettel, M. (2013). Competition-motivated corporate social responsibility. Journal of Business Research, 66, 1954-1963.

Kolk, A., \& Pinkse, J. (2007). Towards strategic stakeholder management? Integrating perspectives on sustainability challenges such as corporate responses to climate change. Corporate Governance, 7(4), 370-378. http://dx.doi.org/10.1108/14720700710820452

Kotler, P., \& Lee, N. (2005). Corporate responsibility: Doing the most good for your company and your cause. Hoboken, New Jersey: Wiley.

Kurucz, E., Colbert, B., \& Wheeler, D. (2008). The business case for corporate social responsibility. In A. Crane, A. McWilliams, D. Matten, J. Moon \& D. Siegel (Eds.), The Oxford Handbook of Corporate Social Responsibility (pp. 83-112). Oxford: Oxford University.

Lewis, J. L., \& Sheppard, S. R. J. (2006). Culture and communication: Can landscape visualization improve forest management consultation with indigenous communities? Landscape and Urban Planning, 77, 291-313.

Lopez, A., Atran, S., Coley, J. D, Medin, D. L., \& Smith, E. E. (1997). The tree of life: universal and cultural features of folkbiological taxonomies and inductions. Coginitive Psychology, 32, 251-295.

Mallin, C.A., \& Michelon, G. (2011). Board reputation attributes and corporate social performance: An empirical investigation of the US best corporate citizens. Accounting and Business Research, 41, 119-144. http://dx.doi.org/10.1080/00014788.2011.550740

Matten, D., \& Moon, J. (2008). Implicit and explicit CSR: A conceptual framework for a comparative understanding of corporate social responsibility. Academy of Management Review, 33(2), 404-424.

Mbare, O. (2007). The Role of corporate social responsibility (CSR) in the new economy. Electronic Journal of Business Ethics and Organisation Studies, 12(2). Retrieved 30 November, 2013, from http://ejbo.jyu.fi/articles/0901_5.html

McKerchar, M. (2008). Philosophical paradigms, inquiry strategies and knowledge claims: Applying the principles of research design and conduct to taxation. eJournal of Tax Research, 6(1). $\quad$ Retrieved $\quad 23 \quad$ September 2013 from http://www.austlii.edu.au/au/journals/eJTR/2008/1.html

Michelon, G., Boesso, G., \& Kumar, K. (2013). Examining the link between strategic corporate social responsibility and corporate performance: An analysis of the best corporate citizens. Corporate Social Responsibility and Environmental Management, 20, 81-94. http://dx.doi.org/10.1002/csr.1278

Monowar, M., \& Humphrey, J. (2013). Stakeholder expectation of corporate social 
responsibility practices: A study on local and multinational corporations in kazakhstan. Corporate Social Responsibility and Environmental Management, 20, 168-181. http://dx.doi.org/10.1002/csr.1283

Neville, B., \& Menguc, B. (2006). Stakeholder multiplicity: Toward an understanding of the interactions between stakeholders. Journal of Business Ethics, 66, 377-391.

Nguyen, C. H. (2007). Email surveys in educational research: Ethical surveys in educational research. Essays in Education, 21, 8-21.

Phillips, R. R., Freeman, R. E., \& Wicks, A. C. (2003). What stakeholder theory is not. Business Ethics Quarterly, 13, 479-502.

Porter, M., \& Kramer, M. (2006). Strategy and society: The link between competitive advantage and corporate social responsibility. Harvard Business Review, 84(12), 78-92.

Post, J. E., Preston, L. E., \& Sachs, S. (2002). Redefining the corporation: stakeholder management and organisational wealth. Palo Alto, CA: Stanford University.

Ramachandran, V. (2011). Strategic corporate social responsibility: A 'Dynamic Capabilities' perspective. Corporate Social Responsibility and Environmental Management, 18(5), 285-293. http://dx.doi.org/10.1002/csr.251

Rangan, K.; Chase, L. A., \& Karim, S. (2012). Why every company needs a CSR strategy and how to build it. Harvard Business School. Retrieved 30 November, 2013, from: http://www.hbs.edu/faculty/Publication\%20Files/12-088.pdf

Rodriguez-Melo, A., \& Mansouri, A. (2011). Stakeholder engagement: Defining strategic advantage for sustainable construction. Business Strategy and the Environment, 20(8), 539-552. http://dx.doi.org/10.1002/bse.715

Schein, E. H. (2010). Organisational culture and leadership (4 ed.). London: John Wiley.

Schwartz, M., \& Carroll, A. (2008). Integrating and unifying competing frameworks: The search for a common core in the business and society field. Business and Society, 47(2), 148-186. http://dx.doi.org/10.1177/0007650306297942

Sharma, A., \& Kiran, R. (2013). Corporate social responsibility: Driving forces and challenges. International Journal of Business Research and Development, 2(1), 18-27.

Simmons, J. (2004). Managing in the post-managerialist era: Towards socially responsible corporate governance. Management Decision, 42(3), 601-611.

Steurer, R. (2010). The role of governments in corporate social responsibility: Characterising public policies on CSR in Europe. Springer Science, 43, 49-72. http://dx.doi.org/10.1007/s11077-009-9084-4

Streiner, D. L. (2003). Being inconsistent about consistency: When coefficient alpha does and doesn't matter. Journal of Personality Assessment, 80(3), 217-222.

Taneja, S., Taneja, P., \& Gupta, R. (2011). Researches in corporate social responsibility: A 


\section{Macrothink}

review of shifting focus, paradigms, and methodologies. Journal of Business Ethics, 101(3), 343-364. http://dx.doi.org/10.1007/s10551-010-0732-6

Tokoro, N. (2007). Stakeholders and corporate social responsibility: A new perspective on the structure of relationships. Asian Business \& Management, 6, 143-162. Retrieved from http://www.palgrave-journals.com/abm/journal/v6/n2/full/9200218a.html

Trevino, L. K., \& Nelson, K. A. (2011). Managing business ethics (5 ed.). London: John Wiley.

Veleva, V. (2010). Managing corporate citizenship: A new tool for companies. Corporate Social Responsibility and Environmental Management, 17(1), 40-51. http://dx.doi.org/10.1002/csr.206

Wong, A., Long, F., \& Elankumaran, S. (2010). Business students' perception of corporate social responsibility: The United States, China, and India. Corporate Social Responsibility and Environmental Management, 17, 299-310. http://dx.doi.org/10.1002/csr.216

Zadek, S. (2000). Doing Good and Doing Well: Making the Business Case for Corporate Citizenship. New York: The Conference (Board Research Report).

\section{Copyright Disclaimer}

Copyright reserved by the author(s).

This article is an open-access article distributed under the terms and conditions of the Creative Commons Attribution license (http://creativecommons.org/licenses/by/3.0/). 